\title{
BRATISLAVSKÝ HRAD A JEHO POTENCIÁL PRE TVORBU KREATÍVNEJ PONUKY V CESTOVNOM RUCHU
}

\author{
Zuzana Palenčíková, Zina Machničová
}

\begin{abstract}
Bratislava castle is the dominant feature of the capital city of Slovakia Bratislava. Located on a hill above the old town, it attracts a thousands of visitors a year. Currently, creative approach to managing and guiding visitors creates the potential of the growth in interest of visitors of museums and cultural heritage sites. This paper summarizes the results of the visitors' survey of Bratislava Castle conducted in the summer season 2017. Among major factors in motivation to visit castle is the unique panoramic view over the river Danube and the whole capital as well as the renovated french baroque garden. Contrarily, the Museum of History, a part of Slovak National Museum, situated in the interiors of the Bratislava castle is less popular among visitors. The paper answears how creative tourism offer can be important for current visitors of Bratislava Castle and how can rise the number of visitors of historic museum in the interiors of the castle.
\end{abstract}

Keywords: Bratislava Castle, creative tourism, cultural heritage site, visitors, tourist product, visitors managment

\section{Úvod}

Kreativita je $\mathrm{v}$ súčasnosti hnacím motorom rozvoja modernej spoločnosti a integrovanou súčast'ou stratégií na zvýšenie ekonomického rastu, podporu inovácií a rozvoj individuálnych zručností ako aj kreatívnych miest. Európska únia už v roku 2009 vyhlásila „rok kreativity a inovácií“, s ciel'om zvýšit' povedomie širokej verejnosti o význame tvorivosti a jej prínose pre ekonomický a sociálny rozvoj Európy ako vedomostnej spoločnosti (EURLEX, 2008). Koncept kreativity je blízky aj cestovnému ruchu. Kreatívny obsah v rôznych typoch cestovného ruchu (napr. kultúrny cestovný ruch, vidiecky cestovný ruch, ekologický cestovný ruch, geoturizmus, gastronomický cestovný ruch, mestský cestovný ruch) sa stal objektom skúmania viacerých vedných disciplín (ekonómia, manažment, marketing, kulturológia, sociológia atd'.) prevažne od začiatku nového milénia.

Východiskovou platformou pre rozvoj kreatívneho cestovného ruchu je kultúrny cestovný ruch, ktorý je dominantný v rámci globálneho cestovného ruchu. V roku 2017 až $46 \%$ (569 mil.) všetkých turistov vo svete cestovalo na základe kultúrnej motivácie (UNWTO, 2018). Pre kultúrne založených turistov majú vel'ký význam lokality kultúrneho dedičstva. Predstavujú kultúrne atraktivity cestovného ruchu, ktoré sú neoddelitel'nou súčast'ou produktu cestovného ruchu 
cielového miesta (destinácie). Častým motívom cestovania kultúrne založených návštevníkov do destinácie je návšteva múzeí. Podl'a Oddelenia pre kultúru, médiá a šport britskej vlády (DCMS, 2005) múzeá pomáhajú svojím návštevníkom pochopit' svoje miesto vo svete a prostredníctvom zachovaného kultúrneho dedičstva spájajú našu minulost' $s$ našou súčasnost'ou aj s našou budúcnost'ou.

Múzeá dnes čelia dvom hlavným výzvam, na jednej strane musia plnit' svoje poslanie ako centrá vzdelávania, výskumu, dokumentovania a uchovávania zbierkových fondov, na strane druhej sa musia dostat' do povedomia rôznorodejšieho publika a byt's ním v interakcii, aby dokázali plnit' svoje poslanie aj v 21. storočí. Globalizácia, digitalizácia a nové technológie „nútia“ múzeá a ich zamestnancov vystúpit' mimo svoju komfortnú zónu a usilovat' sa o inovatívne spôsoby spolupráce s rôznymi komunitami (IT, umelci, remeselníci, školy). Východiskom je uplatňovanie tvorivosti a inovácie vo všetkých činnostiach spojených s manažmentom návštevníka - od procesu prilákania návštevníka do múzea (efektívnou marketingovou komunikáciou a distribúciou), cez tvorbu expozícií, realizáciu prehliadok až po nákup suvenírov a odchod návštevníka.

Na Slovensku je dostupných vyše 100 múzeí, ktoré majú rôzne tematické zameranie. Hradné múzeá patria v cestovnom ruchu medzi najnavštevovanejšie atraktivity cestovného ruchu, čo súvisí s ich romantickým historickým vzhl’adom a často dominantnou polohou v rámci krajiny. Typickým príkladom je Bratislavský hrad, v priestoroch ktorého sídli Historické múzeum - špecializované múzeum v rámci siete múzeí Slovenského národného múzea $(\mathrm{SNM})$. V súlade so svetovým trendom transformácie múzejných expozícií z tradičných statických na moderné centrá interaktívneho a kreatívneho poznávania kultúrno-historického dedičstva sa v príspevku zameriame na súčasnú ponuku hradu a múzea pre návštevníkov a skúmanie ich spokojnosti s návštevou Bratislavského hradu.

\section{Ciel', materiál a metodika}

Ciel'om príspevku je predstavit' Bratislavský hrad ako dominantnú atraktivitu cestovného ruchu hlavného mesta Slovenska a potenciál Historického múzea SNM pre tvorbu kreatívnej ponuky určenej návštevníkom hradu a múzea.

Pri spracovaní príspevku sme uplatnili interdisciplinárny prístup. Ako podklady $\mathrm{k}$ spracovaniu nám slúžili zdroje domácich a zahraničných autorov venované kreativite (Jurčová, 2003, Ullrich, 2016), kreatívnej ekonomike (Mišúnová, 2013, Florida, 2012), kreatívnemu cestovnému ruchu (Richards a Raymond, 2000; Richards a Wilson, 2007) muzeológii (Waltl, 2006, Black a Skinner, 2016) a manažmentu návštevníka (Albrecht, 2017). Informácie sme čerpali aj z rôznych štúdií a teoretických koncepcií, ktoré poukazujú na úzky vzt'ah kreatívneho priemyslu, pamät'ových inštitúcií a cestovného ruchu (OECD, 2014; UNWTO, 2018). Existujúce prieniky medzi cestovným ruchom a kreatívnym priemyslom umožňujú múzeám ako pamätovým inštitúciám zavádzat' moderné 
formy prezentácie, komunikácie a múzejnej edukácie, aj s využitím digitalizácie, informačných technológií a virtuálnej reality a tým sa priblížit’ $\mathrm{k}$ napíňaniu svojho poslania - slúžit' svojím návštevníkom v 21. storočí. V tejto súvislosti sme v letnej sezóne 2017 realizovali dotazníkový prieskum návštevníkov Bratislavského hradu a Historického múzea SNM (211 respondentov), ktorý bol zameraný na identifikáciu silných a slabých stránok v manažmente návštevníkov Bratislavského hradu a odhalenie skrytých príležitostí pre rozvoj kreatívnej ponuky na Bratislavskom hrade a v Historickom múzeu SNM.

\section{Kreativita, kreatívny cestovný ruch a múzeá v 21. storočí}

Kreativita (lat. creatio) nikdy nebola tak aktuálna, ako je tomu dnes. Už nie je výsadou niekol'kých jedincov, ale je považovaná za základnú l'udskú schopnost' (Ullrich, 2016), ktorá je výsledkom interakcie osobnosti s prostredím (Jurčová, 2003). Kreativita sa stala základným zdrojom ekonomického rastu a konkurenčnej výhody v mnohých krajinách, ktoré sú dnes označované ako kreatívne ekonomiky (napr. Fínsko, Estónsko).

Prvé teoretické poznatky o využití kreativity v cestovnom ruchu nachádzame v prácach Richards a Raymond (2000), ktoré sa zaoberajú teoretickou diskusiou o kreativite ako potenciálnom spúštači rozvoja ciel'ových miest cestovného ruchu $\mathrm{v}$ spojitosti $\mathrm{s}$ fenoménom rozvoja kreatívnej triedy (Florida, 2012) a kreatívnych odvetví (DCMS, 1998). Richards a Raymond, (2000, s. 18) na začiatku 2. milénia definovali kreatívny cestovný ruch ako "cestovný ruch, ktorý ponúka návštevníkom príležitost' rozvíjat' svoj tvorivý potenciál prostredníctvom aktívnej účasti na rôznych kurzoch a zážitkovom učení, ktoré sú charakteristické pre ciel'ové miesta, v ktorom sa uskutočňujú“. Kreatívny cestovný ruch vo svete postupne formovali nové príležitosti na trhu (digitálne technológie, masívny nástup internetu, trend glokalizácie), pod vplyvom ktorých sa menil aj jeho obsah a dnes môžeme kreatívny cestovný ruch vymedzit' v ovel'a širších dimenziách ako „budovanie vzt'ahov medzi návštevníkom a destináciou s využitím kreatívnych odvetvi'“ (Sano, 2016, s. 129).

Základným predpokladom pre rozvoj kreatívneho cestovného ruchu je kreatívny návštevník, ktorý hl'adá zážitok uspokojujúci jeho túžbu po poznaní formou interakcie s miestnou komunitou umelcov, remeselníkov a pod. Z pasívneho návštevníka sa stáva kreatívny návštevník, ktorý je spolutvorcom svojho zážitku (Richards a Raymond, 2000, Tan et al., 2014). Kreatívni l'udia, ktorí podl'a Floridu (2012) predstavujú kreatívnu triedu, sú prirodzene prit’ahovaní rozmanitými a živými miestami, ktoré sa stali atraktívne a prosperujúce vd’aka prítomnosti kreatívneho sektora.

Múzeá ako súčast' kreatívneho sektora majú za úlohu sprístupňovat' výsledky svojej činnosti verejnosti najmä prostredníctvom stálych expozícií, výstav a popularizačných aktivít, ktorými svojich návštevníkov inšpirujú $\mathrm{k}$ 
tvorivosti, celoživotnému vzdelávaniu a podporujú ich zvedavost'. Návštevníci od návštevy očakávajú interakciu, vzrušujúce programy a náročné výstavy, prostredníctvom ktorých dosiahnu nielen vzdelávacie zážitky, ale aj zábavu a sebarealizáciu (Waltl, 2006). Transformačný proces v múzeách od „,produktu“ (tradičná prezentácia) smerom k „publiku“ (kreatívna interakcia s návštevníkom) je podl'a Waltla (2006) nevyhnutný, ak chcú múzeá prežit'. Hlavným faktorom rozhodovania o návšteve múzea už nie je iba kvalita zbierky, ale klúčovým sa stáva prostredie múzea a možnosti interakcie s návštevníkom. Moderné múzeum zamerané na publikum má dynamický charakter, založený na dialógu a budovaní vzt’ahov s návštevníkmi, a to najmä rôznymi programovými a marketingovými aktivitami (obr. 1).

Obr. 1: Model budovania publika v múzeu

Figure 1: Audience Development Model

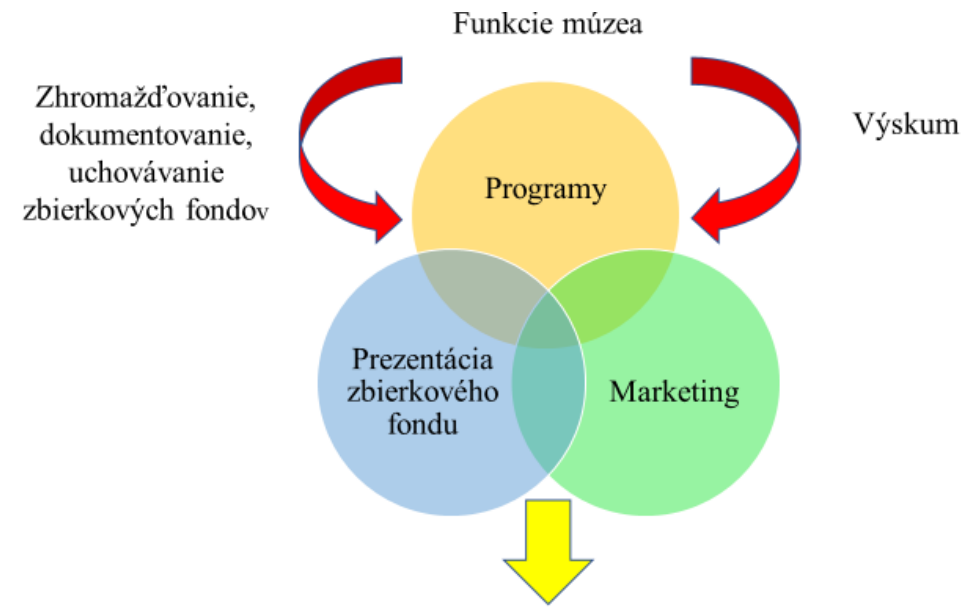

Budovanie publika

Zdroj: Waltl, 2006

Dnešní návštevníci zvyčajne navštevujú múzeum v rodinných alebo iných spoločenských skupinách s ciel’om kvalitne a plnohodnotne strávit' spolu čas. Síce majú túžbu učit' sa a poznávat' nové veci, rozširovat' svoje horizonty a/alebo stimulovat' svoje deti, ale očakávajú, aby návšteva bola v ich podmienkach.

Kreatívny cestovný ruch je pre múzeá potenciálnym zdrojom návštevníkov, ktorí sú motivovaní spoznávat' históriu, kultúru a kultúrne dedičstvo v múzeách kreatívnym spôsobom, účastou na rôznych formách zážitkového učenia. Zapojenie múzeí do kreatívneho cestovného ruchu ponúka synergické efekty pre obidve strany: 
- múzeá s kreatívnou ponukou majú potenciál oslovit' viac návštevníkov, ktorí hl'adajú kvalitné využitie svojho vol'ného času a dosiahnut' hospodárske a sociálne inovácie (Mišúnová, 2013);

- návštevníci získajú pridanú hodnotu v podobe aktívneho „zapojenia“ sa do prehliadky múzea, stávajú sa spolutvorcami svojho komplexného zážitku (Black a Skinner, 2016).

Príkladom takejto synergie je projekt Erasmus+ „Kreatívne múzeum“, realizovaný v rokoch 2014-2017 v rámci siete európskych múzeí a kultúrnych organizácií. Ciel'om projektu bolo preskúmat' kreatívnu prax a participatívne programy, ktoré múzeá realizujú v spolupráci s miestnymi umelcami, tradičnými umeleckými remeselníkmi, podnikmi kreatívneho priemyslu a poskytovatel'mi digitálnych služieb a navrhnút' procesy pre zavedenie inovatívnych spôsobov aktívneho kreovania zážitku a budovania vzt'ahov s návštevníkmi múzea. Výstupom projektu je súbor odporúčaní pre múzeá, ktoré majú záujem proaktívne vytvárat' kreatívne prostredie a ponuku pre svojich návštevníkov a zároveň zvyšovat' kvalifikáciu svojich zamestnancov. Pre zavedenie kreatívnej ponuky v múzeu sú klúčcové nasledovné kroky (www.creative-museum.net, 2018):

- spojit' sa a spolupracovat' $\mathrm{s}$ komunitami výskumníkov, umelcov, umeleckých remeselníkov, IT odborníkov, škôl atd'. a otvorit' sa novému publiku,

- vytvorit' priestor pre experimentovanie, zdiel'anie a hru, napr. laboratórium, kreatívne centrum, kde návštevník môže objavovat' vystavené objekty a kde sa môžu realizovat' rôzne interaktívne podujatia s návštevníkmi múzea a spolupracujúcimi komunitami (workshopy, semináre, kurzy...),

- stratégie pre úspech, tvorené $\mathrm{v}$ spolupráci $\mathrm{s}$ rôznymi komunitami (podnikatelia, IT odborníci, umelci, atd'.) a zamestnancami. Implementáciou uvedených odporúčaní múzeá môžu pozitívne ovplyvnit' počty svojich návštevníkov, zvýšit' svoje tržby a zároveň zlepšit' pracovné podmienky svojich zamestnancov.

\section{Bratislavský hrad ako objekt záujmu návštevníkov cestovného ruchu}

Bratislavský hrad je neodmyslitel'nou súčast'ou panorámy hlavného mesta Slovenska - Bratislavy. Svojou polohou nad riekou Dunaj a starým mestom prit’ahuje pozornost' návštevníkov prichádzajúcich do Bratislavy. Jeho súčasný obraz je výsledkom rozsiahlych rekonštrukcií (obr. 2), ktorých ciel’om bola obnova hradu zo stavu ruiny (rekonštrukcia v rokoch 1953 - 1968) a prinavrátenie hradného paláca a celého areálu hradu do podoby poslednej barokovej etapy pred vel'kým požiarom v roku 1811 (rekonštrukcia v rokoch 2008 - 2016).

Z historického hl'adiska predstavuje hradný areál mimoriadne významnú lokalitu. Najstaršie osídlenie hradného vrchu siaha do čias eneolitu (cca 2500 
rokov p.n.1.) (Plaček, Bóna, 2007), najstaršie dochované architektonické pamiatky (murované stavby s ozdobnou dlažbou) pochádzajú spred viac ako 2000 rokov, z obdobia, ked' sa na území dnešnej Bratislavy rozkladalo keltské oppidum. Verejnosti sú sprístupnené po poslednej rekonštrukcii v podzemnom priestore pod nádvorím Bratislavského hradu (www.snm.sk, 2018). Významné osídlenie dokumentujú pozostatky stavieb z obdobia Vel'kej Moravy zachované v blízkosti hradného paláca. Po zániku Vel'komoravskej ríše postupne hrad prešiel viacerými stavebnými úpravami, gotickou (postavená nová obytná veža - donžon) aj renesančnou (v rokoch 1552 - 62; Bratislava sa stala po obsadení Budína v r. 1529 Osmanmi hlavným mestom Uhorska a sídlom Habsburgovcov). Poslednou vel'kou prestavbou hrad prešiel za vlády Márie Terézie (1740 - 1780), kedy nadobudol súčasnú podobu (prístavba tzv. Tereziána, jazdiarne, hospodárskeho dvora a francúzskej barokovej záhrady) (www.bratislava-hrad.sk, 2018).

Obr. 2: Bratislavský hrad po poslednej rekonštrukcii (2008 - 2016)

Figure 2: Bratislava Castle after the last reconstruction (2008- 2016)

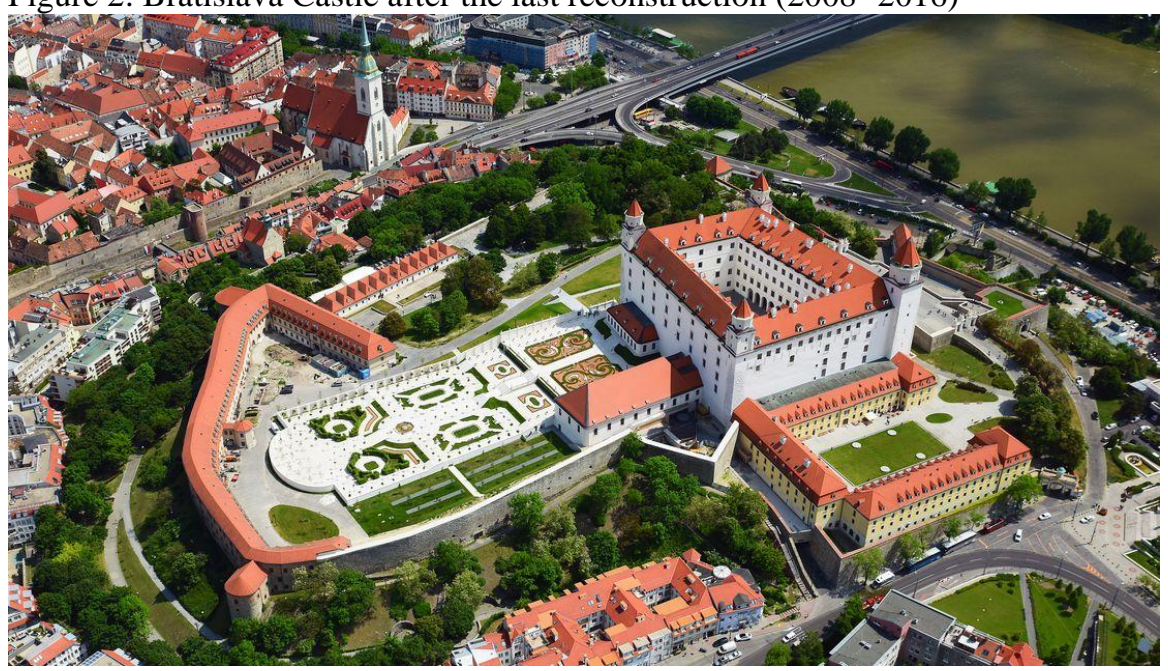

Zdroj: www.cas.sk, 2018

V súčasnosti je hrad vo vlastníctve NR SR. V jeho priestoroch sídli Historické múzeum SNM, zamerané na dokladovanie vývinu spoločnosti na Slovensku od najstarších čias až po súčasnost'. Okrem stálej expozície múzeum pre verejnost' pravidelne pripravuje rôzne tematické výstavy, ktoré súvisia s historickým vývojom na Slovensku a v Európe (tab. 1). Medzi d’alšie popularizačné činnosti múzea, ktorými sa snaží viac otvorit' širokej verejnosti a budovat' si stabilné publikum návštevníkov, patrí organizácia kultúrnovzdelávacích podujatí ako sú tvorivé dielne, workshopy, komentované prehliadky 
$\mathrm{k}$ tematickým výstavám, či spolupráca so základnými školami. V rámci projektu „Škola v múzeu“ realizuje interaktívne vzdelávacie programy pre žiakov ZŠ a SS̆ o dejinách Bratislavského hradu, o živote l'udí na území Slovenska od praveku po Vel'kú Moravu, o st’ahovaní národov, pričom využíva kreatívny prístup a aktívnu účast' žiakov s využitím rôznych didaktických pomôcok a tematických pracovných listov.

Tab. 1: Kalendár výstav Historického múzea SNM na Bratislavskom hrade Table 1: Calendar of Exhibitions of the Historical Museum at the Bratislava Castle

\begin{tabular}{|l|l|c|}
\hline Por. & \multicolumn{1}{|c|}{ Názov výstavy } & \multicolumn{1}{c|}{ Termín } \\
\hline 1. & Martin Benka & $21.9 .2018-31.12 .2019$ \\
\hline 2. & $\begin{array}{l}\text { Severné reprezentačné priestory } \\
\text { Bratislavského hradu }\end{array}$ & $1.9 .2018-31.12 .2020$ \\
\hline 3. & Klenotnica & $28.6 .2018-31.12 .2020$ \\
\hline 4. & Reklama a obchod 1918-1948 & $18.7 .2017-30.11 .2018$ \\
\hline 5. & Kelti z Bratislavy & $15.12 .2016-2.5 .2019$ \\
\hline 6. & Bratislavský hrad na grafikách & $19.5 .2012-31.12 .2020$ \\
\hline 7. & Obnova Bratislavského hradu & $17.11 .2011-31.12 .2020$ \\
\hline
\end{tabular}

Zdroj: www.snm.sk, 2018

Na prilákanie návštevníkov Historické múzeum využíva štandardné spôsoby propagácie svojich aktivít a programov, najmä webovú stránku SNM, profilovú stránku na Facebooku a príležitostne pri vel'kých a významných výstavách aj finančne nákladnejšiu reklamu v televízii.

\section{Prieskum návštevnosti Bratislavského hradu a Historického múzea SNM}

Návštevnost' je jedným zo základných ukazovatel'ov, prostredníctvom ktorých sa meria popularita a „spotreba“ atraktivít kultúrneho dedičstva. Návštevnost' všetkých expozícií, výstav a kultúrno-vzdelávacích podujatí Historického múzea SNM v roku 2017 bola 114153 osôb, čo je v medziročnom porovnaní nárast návštevnosti takmer o $25 \%$ (tab. 2). Ak však vezmeme do úvahy skutočnost', že v roku 2016 hrad fungoval v obmedzenom režime z dôvodu využitia jeho priestorov pre štátnu reprezentáciu počas Predsedníctva SR v Rade EÚ, zistíme, že návštevnost' hradu sa nezvyšuje, ale dlhodobo stagnuje, aj napriek novej expozícií Dejín Slovenska od praveku po Vel'kú Moravu, sprístupnenej v januári 2016. 
Tab. 2: Vývoj návštevnosti Bratislavského hradu v rokoch 2012 - 2017

Table 2: Visitors Statistics of Bratislava Castle in $2012-2017$

\begin{tabular}{|l|c|c|c|c|c|c|}
\hline \multicolumn{1}{|c|}{ Rok } & $\mathbf{2 0 1 2}$ & $\mathbf{2 0 1 3}$ & $\mathbf{2 0 1 4}$ & $\mathbf{2 0 1 5}$ & $\mathbf{2 0 1 6}$ & $\mathbf{2 0 1 7}$ \\
\hline $\begin{array}{l}\text { Počet } \\
\text { návštevníkov }\end{array}$ & 119659 & 125 & 120051 & 120708 & 91430 & 114 \\
& & 085 & & & & \\
\hline
\end{tabular}

Zdroj: Historické múzeum SNM, 2018

Návštevnost' Historického múzea SNM na Bratislavskom hrade stagnuje aj v porovnaní $\mathrm{s}$ narastajúcim počtom domácich a zahraničných návštevníkov, ktorí realizovali v Bratislave minimálne jedno prenocovanie (tab. 3).

Tab. 3: Návštevnost' Bratislavy podl'a ubytovacej štatistiky v rokoch $2012-2017$ Table 3: Stayover Visitors of the city of Bratislava according to the accommodation statistics in $2012-2017$

\begin{tabular}{|l|c|c|c|c|c|c|}
\hline \multicolumn{1}{|c|}{ Rok } & $\mathbf{2 0 1 2}$ & $\mathbf{2 0 1 3}$ & $\mathbf{2 0 1 4}$ & $\mathbf{2 0 1 5}$ & $\mathbf{2 0 1 6}$ & $\mathbf{2 0 1 7}$ \\
\hline $\begin{array}{l}\text { Domáci } \\
\text { návštevníci }\end{array}$ & 265259 & 299970 & 131624 & 342536 & 395234 & 419692 \\
\hline $\begin{array}{l}\text { Zahraniční } \\
\text { návštevníci }\end{array}$ & 558153 & 647760 & 712900 & 722292 & 831151 & 871316 \\
\hline $\begin{array}{l}\text { Návštevníci } \\
\text { spolu: }\end{array}$ & 823412 & 947730 & 844524 & 1064828 & 1226385 & 1291008 \\
\hline
\end{tabular}

Zdroj: BTB, 2018

Tretina domácich návštevníkov (33 \%) pochádzala z Bratislavy a okolia. Zvyšní respondenti pochádzali z rôznych miest Slovenska. Najväčší podiel na zahraničnej návštevnosti mali návštevníci z Českej republiky (18\%), Španielska (11\%), Rakúska (9\%), Nemecka (8\%), Ćíny (8\%), Pol'ska (7 \%) a Francúzska (7 $\%)$. Z ostatných krajín mali v prieskume zastúpenie respondenti z Mad'arska, Ruska, Spojeného královstva, Talianska, Portugalska, USA, Kanady a Mexika. Z prieskumu vyplýva, že okrem tradičných trhov (domáci návštevník a návštevníci z okolitých krajín) sa hrad stáva populárnou atraktivitou cestovného ruchu aj pre návštevníkov zámorských krajín (Č́ína, USA, Kanada, Mexiko).

Dôležitým aspektom, na základe ktorého sa návštevníci rozhodujú o návšteve turistickej atraktivity (napr. múzea), je dostupnost' informácií. Najväčším zdrojom informácií o Bratislavskom hrade pre domácich návštevníkov bola škola, ktorú označilo až $43 \%$ respondentov. Druhým najčastejším zdrojom boli odporúčania známych (17\%). Nasledovali televízia a iné médiá $(16 \%)$. Internet pri hl'adaní informácií o hrade u domácich návštevníkov nezohrával až takú významnú úlohu, označilo ho len $10 \%$ respondentov. Naopak, u zahraničných návštevníkov bol internet hlavným zdrojom informácií (35\%) a odporúčania známych (23\%). Ako d’alšie zdroje informácií zahraniční návštevníci označili knižných sprievodcov (17\%), propagačné prospekty a iné materiály (6\%). Služby 
cestovných kancelárii a sprievodcov pri vyhl'adávaní informácií o hrade využilo iba 7\% zahraničných návštevníkov, rovnako aj služby TIC (4 \%).

Súčastou prieskumu boli d’alej motívy návštevy a hodnotová orientácia návštevníkov, $\mathrm{v}$ tejto súvislosti domáci návštevníci hradu uviedli, že sú milovníkmi histórie (18\%), zahraniční návštevníci hradu najčastejšie cestovali s ciel'om vzdelávat' sa a získavat' nové informácie (15\%), d’alej za umením a netradičnými a originálnymi vecami $(14 \%)$. Táto možnost' bola u domácich návštevníkov na druhom mieste (13\%). Významná čast' domácich návštevníkov sa označila za vyznávačov originality (11\%), ale aj fanúšikov dobrého jedla, umenia či filmových vyznávačov (8\%). Medzi hlavné motívy, ktoré viedli domácich návštevníkov k návšteve hradu patrí: užit' si panoramatický výhl'ad na Bratislavu (29\%), čas strávený s rodinou, priatel'mi (22\%), záujem spoznat' hrad (22\%), zmysluplne strávit' vol’ný čas počas služobných povinností v hlavnom meste $(18 \%)$ a $3 \%$ sa rozhodli navštívit' hrad, pretože ich zaujali informácie na internete. U zahraničných návštevníkov prevažovala túžba užit'si panoramatický výhl'ad (32\%), záujem spoznat' hrad - dominantu Bratislavy (26\%), zmysluplne strávit' vol'ný čas počas služobných povinností v hlavnom meste (12\%) a iba $11 \%$ z nich prišlo s ciel'om strávit' čas s rodinou alebo priatel'mi. Návšteva múzeí, hradov a zámkov je často hlavným motívom a ciel’om návštevy širšej turistickej destinácie. Pre $23 \%$ domácich a $28 \%$ zahraničných návštevníkov bola návšteva Bratislavského hradu hlavným ciel'om ich cesty do Bratislavy, pre 39 \% domácich a $46 \%$ zahraničných návštevníkov bola jedným z bodov programu počas návštevy Bratislavy a $38 \%$ domácich a $26 \%$ zahraničných návštevníkov sa rozhodlo navštívit' hrad spontánne, až po príchode do hlavného mesta. Medzi návštevníkmi Bratislavského hradu dominovali individuálni návštevníci, organizovane (zájazdy CK a školské exkurzie) hrad navštívilo $35 \%$ zahraničných a iba $9 \%$ domácich respondentov.

Pre manažment Historického múzea SNM na Bratislavskom hrade je klúčcové poznanie, kol'kí respondenti si počas návštevy hradného areálu prezreli len exteriér hradu (nádvorie, baroková záhrada, panoramatický výhl’ad) a kol'kí na hrad prišli primárne kvôli expozícií Historického múzea SNM, umiestnenej $\mathrm{v}$ interiéroch hradu. $\mathrm{Z}$ domácich respondentov sa $58 \%$ zaujímalo iba o exteriér hradu, $42 \%$ prejavilo záujem aj o prehliadku expozície SNM. Ani jeden domáci respondent neprišiel na hrad výlučne iba kvôli návšteve múzea. U zahraničných respondentov až $64 \%$ prejavilo záujem navštívit' exteriér aj interiér hradu a 35\% sa zaujímalo aj o prehliadku exteriéru, iba jeden zahraničný respondent prišiel na hrad výlučne kvôli návšteve múzea.

Spokojný návštevník múzea znamená lojálny návštevník, ktorý sa opakovane vracia a šíri jeho dobré meno. Respondenti svoju spokojnost' alebo nespokojnost' so službami na hrade vyjadrili prostredníctvom Likertovej škály, pričom hodnotenie 1 znamenalo absolútnu spokojnost' a hodnotenie 5 absolútnu nespokojnost'. Domáci respondenti boli najviac spokojní s čistotou priestorov 
hradného areálu $(1,4)$ a flexibilnými otváracími hodinami $(1,5)$. Vel'mi dobré hodnotenie dosiahla aj expozícia Historického múzea SNM $(1,7)$, výskyt a umiestnenie informačných tabúl' v okolí hradu $(1,8)$. Známku 2 dostala turistická vybavenost' hradu (dostupnost' lavičiek a WC vexteriéri) a predajné miesto vstupeniek do expozície SNM. Najmenej spokojní boli respondenti s cenou vstupného do expozície SNM $(2,9)$, ktorej výška mohla mnohých návštevníkov odradit' od prehliadky interiéru hradu. Zahraniční respondenti boli oproti domácim menej kritickí $\mathrm{k}$ turistickej vybavenosti hradu $(1,6)$, či cenám vstupného do interiéru hradu $(2,2)$. Nespokojnejší oproti domácim boli s predajným miestom vstupeniek do expozície SNM interiéru $(2,1)$, k rozmiestneniu informačných tabúl' (2), či expozícii SNM $(2,2)$. Menšia spokojnost' návštevníkov s cenou vstupného do múzea súvisí s hodnotou, ktorú im múzeum poskytuje za vynaložené peniaze. Ide o komplexný zážitok, ktorý zodpovedá výške vstupného.

Súčastou skúmania spokojnosti bol aj najväčší zážitok spojený s návštevou hradného areálu. Domáci aj zahraniční respondenti sa jednoznačne zhodli (domáci v počte $59 \%$, zahraniční $50 \%$ ), že najväčším zážitkom bola možnost' vychutnat' si panoramatický výhl'ad na Bratislavu, druhý najväčší dojem v nich zanechala novo zrekonštruovaná baroková záhrada v exteriéri hradu (25\% domácich a 32\% zahraničných respondentov). Nasledovala architektúra hradu (9\% domáci a $7 \%$ zahraniční respondenti). Prehliadka expozície Historického múzea SNM najviac zaujala iba $7 \%$ zahraničných a $3 \%$ domácich respondentov.

V nadväznosti na spokojnost' návštevníkov s návštevou Bratislavského hradu nás zaujímalo, či budú jeho návštevu odporúčat' svojim priatel'om a známym. Výsledky sú vel’mi pozitívne, viac ako polovica domácich $(55 \%)$ a polovica zahraničných respondentov sa vyjadrila, že návštevu hradu určite odporučí, o niečo menej respondentov (37\% domácich a $35 \%$ zahraničných) uviedlo, že pravdepodobne áno.

Poslednou skúmanou problematikou boli služby, ktorých absenciu návštevníci hradu a múzea vnímali najvypuklejšie. Odpovede respondentov zároveň môžu slúžit' ako podnet na zlepšenie už existujúcej ponuky služieb v múzeu a hradnom areáli. Návštevníkom Bratislavského hradu najviac chýbala virtuálna prehliadka hradu na internete (uviedlo 38\% domácich a $28 \%$ zahraničných respondentov). Ďalším súvisiacim problémom bola absencia oficiálnej webovej stránky hradu na internete ako oficiálnej „virtuálnej brány“ na hrad. Pre návštevníka v cestovnom ruchu je dnes internet hlavným zdrojom informácií o cestovných ciel'och, podl'a španielskeho cestovatel'ského portálu hosteltur.com (Carvalho et al., 2016) l'udia navštívia v priemere až 23 webových stránok pred výberom svojej turistickej destinácie. Pri zadaní kl'účového hesla „Bratislavský hrad“ alebo „Bratislava Castle“ internetový prehliadač ponúka linky na rôzne stránky (tab. 4), pričom len zopár z nich bolo možné otvorit’ aj v cudzom jazyku (najčastejšie anglický a nemecký jazyk). Oficiálny prevádzkovatel' múzea na hrade - SNM, sa nachádzal až na 5. pozícii, pri zadaní anglického variantu sa 
vôbec neobjavil vo výbere na prvých 10 pozíciách. Aj to je dôvod, prečo $9 \%$ zahraničných respondentov uviedlo, že im na internete chýbala oficiálna a jednotná propagácia hradu, kde by našli všetky potrebné informácie na jednom mieste. S internetovým prostredím súvisí d’alší problém hradu ako atraktivity cestovného ruchu v 21. storočí, ktorým je podl'a respondentov online predaj vstupeniek a prevádzkovanie e-shopu so suvenírmi. Na absenciu online predaja vstupeniek poukázalo $25 \%$ domácich a $20 \%$ zahraničných respondentov.

Tab. 4: Webové stránky s turistickými informáciami o Bratislavskom hrade Table 4: Web pages with the Tourist Information about the Bratislava Castle

\begin{tabular}{|c|c|c|c|}
\hline \multicolumn{4}{|c|}{ Kl'účové slovo } \\
\hline Bratislavský hrad & $\begin{array}{c}\text { Jazykové } \\
\text { mutácie }\end{array}$ & Bratislava Castle & $\begin{array}{c}\text { Jazykové } \\
\text { mutácie }\end{array}$ \\
\hline sk.wikipedia.org & SJ & en.wikipedia.org & AJ \\
\hline $\begin{array}{c}\text { www.bratislavskyhrad.eu } \\
\text { (prevádzkuje Atlas.sk) }\end{array}$ & SJ & $\begin{array}{c}\text { www.visitbratislava.com } \\
\text { (prevádzkuje Bratislavská } \\
\text { turistická organizácia) }\end{array}$ & SJ, AJ, NJ \\
\hline $\begin{array}{c}\text { www.bratislava-hrad.sk } \\
\text { (prevádzkuje Kancelária } \\
\text { NR SR) }\end{array}$ & SJ & $\begin{array}{c}\text { www.slovakia.com } \\
\text { (prevádzkuje CA Region } \\
\text { Slovakia, s.r.o.) }\end{array}$ & SJ, AJ \\
\hline $\begin{array}{c}\text { www.vyletik.eu } \\
\text { (prevádzkovatel } \\
\text { WebGrafix.sk) }\end{array}$ & SJ & $\begin{array}{c}\text { slovakia.travel (národný } \\
\text { turistický portál) }\end{array}$ & $\begin{array}{c}\text { SJ, AJ, NJ, } \\
\text { HU, PL, RU, } \\
\text { CJJ }\end{array}$ \\
\hline $\begin{array}{c}\text { www.snm.sk (prevádzkuje } \\
\text { SNM) }\end{array}$ & SJ, AJ & www.tripadvisor.co.uk & AJ \\
\hline
\end{tabular}

Zdroj: vlastné spracovanie, 2018

Z uvedených zistení vyplýva, že najväčšie nedostatky návštevníci hradu pocit’ujú najmä $\mathrm{v}$ oblasti internetového prostredia a informačných technológií, ktoré sú v dnešnej dobe nevyhnutnou súčast'ou komunikácie s ciel’ovým publikom a zároveň distribučným a odbytovým kanálom (online predaj vstupeniek a suvenírov). Tret'ou najčastejšie chýbajúcou službou na hrade $\mathrm{z}$ pohl'adu návštevníkov bol audio sprievodca (23 \% domácich a $45 \%$ zahraničných respondentov), QR kódy (15 domácich a $32 \%$ zahraničných respondentov) a informačno-navigačné tabule ( $20 \%$ domácich a $18 \%$ zahraničných respondentov). Tieto sa síce na hrade nachádzajú, ale sú horšie viditel'né a osadené na miestach, kde ich návštevníci zväčša nehl'adajú. Ďalšími chýbajúcimi službami sú animačné služby na hrade a v múzeu (7 \% domácich a 12 \% zahraničných návštevníkov).

\section{Potenciál Bratislavského hradu pre tvorbu kreatívnej ponuky}

Súčasný návštevník Bratislavského hradu od jeho návštevy očakáva autentický zážitok, plný histórie, originálnych a netradičných zážitkov. Na základe 
výsledkov prieskumu konštatujeme, že ide o návštevníka so záujmom o poznávanie, zmysluplné využitie vol'ného času a čas strávený s rodinou a priatel'mi. Existuje preto vysoký predpoklad, že bude motivovaný aktívne sa zúčastňovat' na rôznych vzdelávacích aktivitách alebo kreatívnych kurzoch, ktoré sú založené na poznávaní miestnej kultúry.

Bratislavský hrad vytvára pre Historické múzeum SNM atraktívnu kulisu a priestor pre interakciu s návštevníkmi hradu, ale tento potenciál nevyužíva naplno. Múzeum napriek uplatňovaniu prvkov kreativity pri tvorbe svojich programov ako sú tematické výstavy, workshopy, tvorivé dielne či programy pre základné a stredné školy, nevie upútat' značnú čast' návštevníkov hradného areálu, najmä z radov turistov. Takmer $60 \%$ domácich a $35 \%$ zahraničných návštevníkov počas nášho prieskumu neplánovalo návštevu múzea na hrade, čo môže súvisiet' so slabou propagáciou, následnou nízkou informovanost'ou návštevníkov o aktivitách múzea a z toho vyplývajúcou absenciou ich záujmu zdržat' sa na hrade dlhšie ako je čas potrebný na prehliadku exteriéru. Môžeme predpokladat', že očakávaný zážitok $\mathrm{z}$ prehliadky múzea u súčasného návštevníka neprevyšuje zážitok z exteriéru hradu. Dnes už nestačí byt' kreatívny „vnútri“, po vstupe návštevníka do múzea, potrebné je byt' kreatívny aj proaktívne, v nadväzujúcich krokoch, ktoré predchádzajú vstupu návštevníka do múzea. V prípade Historického múzea na Bratislavskom hrade to znamená zaviest' tzv. manažment návštevníka, t. z. uplatnit' vhodné manažérske nástroje a opatrenia, ktoré prinesú pozitívne zmeny v počte a správaní návštevníkov a umocnia zážitok a jeho hodnotu v očiach návštevníka (Albrecht, 2017). Pre lepšie využitie kreativity v prospech zvýšenia návštevnosti Historického múzea SNM je potrebné uskutočnit' opatrenia v štyroch kl'účových oblastiach:

1. Kreatívna komunikácia s návštevníkom na internete. Podl’a výsledkov prieskumu pre d'alší rozvoj múzea je nevyhnutné vytvorit' samostatnú webovú domovskú stránku vo viacerých svetových jazykoch, ktorá bude slúžit' pre potenciálnych návštevníkov ako prvý a hlavný zdroj informácií o múzeu (otváracie hodiny, vstupné, aktuálne programy), bude poskytovat' virtuálnu prehliadku múzea a zároveň bude slúžit' ako odbytový kanál na online predaj vstupeniek a upomienkových predmetov.

2. Digitalizácia múzea. Zapojenie múzea do digitalizácie sa netýka iba vlastnej webovej stránky, ale je to aj práca so sociálnymi siet’ami (Facebook, Instagram), využívanie audiosprievodcov, QR kódov pri exponátoch, mobilných aplikácií, rôznych online hier či nástrojov elektronického vzdelávania. Digitálne zapojenie múzea umožní prilákat' najmä mladšiu generáciu, ktorá považuje za samozrejmost' okamžité použitie a spotrebu a rovnako aj zdiel'anie zážitku.

3. Spolupráca s miestnou komunitou kreatívnych pracovníkov. Zaradenie animačných aktivít do programu múzea vyžaduje vytvorenie fungujúcej 
siete lektorov (histórie, umenia) s miestnymi umelcami, remeselníkmi a pod.. Pravidelné animačné programy s využitím „miestneho príbehu“ a „genius loci“ sú dnes populárnou formou prezentácie v múzeách (napr. rakúsky barokový zámok Hof so statkom ned’aleko Bratislavy). Animované prehliadky $v$ hradných múzeách sú dnes rovnako samozrejmost'ou. Okrem animácie môžu participovat' na kreatívnom poznávaní miestnej histórie organizovaním tvorivých dielní, kde by si návštevníci mohli vyrobit' napr. vlastný suvenír inšpirovaný témou prehliadky/výstavy, alebo konkrétnym exponátom.

4. Úzka spolupráca so sektorom cestovného ruchu - s miestnymi podnikmi cestovného ruchu (ubytovacie a stravovacie zariadenia), s domácimi a zahraničnými cestovnými kanceláriami a oblastnou a krajskou organizáciou cestovného ruchu, jednak pri propagácii, ale najmä pri tvorbe programových balíkov, kde by prehliadka Bratislavského hradu okrem hradného areálu v exteriéri obsahovala aj návštevu Historického múzea SNM, spojenú s konkrétnym animačným programom.

Navrhované opatrenia majú potenciál zvýšit' súčasnú stagnujúcu návštevnost' múzea zo strany domácich aj zahraničných hostí a priniest' múzeu dodatočné príjmy z nárastu tržieb zo vstupného. Ide o finančne, personálne aj organizačne náročné úlohy, ktoré sú bez podpory manažmentu SNM a kancelárie NR SR t’ažko realizovatel'né.

\section{Záver}

Múzeá ako centrá poznania dnes čelia transformačným procesom pod vplyvom nástupu nových technológií a narastajúcich očakávaní a požiadaviek súčasných návštevníkov. Ekonomické transformačné procesy spojené s postupným trendom znižovania verejného financovania múzeí $\mathrm{v}$ praxi znamenajú, že pracovníci múzeí musia byt' vo svojej práci stále viac vynaliezaví a kreatívni; paradoxne sa od nich očakáva rozvoj a rast $\mathrm{s}$ ciel'om napĺn̆at' hlavné poslanie múzea, ale so zníženými dostupnými zdrojmi.

Múzeá a lokality kultúrneho dedičstva sú v zmysle Stratégie rozvoja kreatívneho priemyslu v SR súčastou kreatívnych odvetví, ktoré by mali v rámci svojej hlavnej činnosti ekonomicky zhodnocovat' svoj kreatívny potenciál. Vo vel'kej miere môže $\mathrm{k}$ ich ekonomickému rastu prispiet' ciel'avedomá spolupráca so sektorom cestovného ruchu, ktorý predstavuje pre múzeá a ostatné pamätové inštitúcie významný odbytový kanál a zdroj potenciálnych návštevníkov. Prínosy takejto spolupráce pre sektor cestovného ruchu možno v súčasnosti nepriamo vyčíslit' prostredníctvom satelitného účtu cestovného ruchu ako podiel iných služieb na cestovnom ruchu (kultúra, rekreácia, iné zábavné služby a d’alšie služby). Pre dlhodobú prosperitu a rozvoj múzeí je preto potrebné aktívne plánovat' stratégie zamerané na návštevníka, ktoré budú uplatňovat' holistický 
prístup s prepojením aj na iné súvisiace sektory (kreatívne odvetvia, školstvo), vrátane cestovného ruchu. Ide o dlhodobú víziu, založenú na spolupráci a spoločných ciel’och múzeí $\mathrm{s}$ rôznymi zainteresovanými aktérmi $\mathrm{z}$ verejného a súkromného sektora.

\section{Pod'akovanie}

Príspevok bol spracovaný $v$ rámci riešenia projektu VEGA 1/0169/18 Kreativny cestovný ruch ako nový produkt cestovného ruchu na Slovensku.

\section{Literatúra}

ALBRECHT, J. N. 2017. Visitor Management in Tourism Destinations. Boston: CAB International, 2017. 200 p. ISBN 978-1-78064-735-7.

BLACK, G. - SKINNER, D. 2016. The innovation in Museum Displays Project. [online]. 2016. [cit. 2018-09-10]. Dostupné na internete: <http://www.innovationinmuseumdisplays.co.uk/uploads/1/8/9/7/1897065/full _report_innovation_in_museum_displays.pdf>

BTB. 2018. Śtatistiky a prieskumy. [online]. 2018. [cit. 2018-09-10]. Dostupné na internete: <https://www.visitbratislava.com/sk/media/statistiky/>

CARVALHO, R. - FERREIRA, A. M. - FIGUEIRA, F. M. 2016. Cultural and Creative tourism in Portugal. In PASOS. Revista de Turismo y Patrimonio Cultural. [online]. 2016, vol.14, no. 5 [cit. 2017-01-10]. Dostupné na internete: https://doi.org/10.25145/j.pasos.2016.14.071> ISSN 1695-7121.

CREATIVE MUSEUM PROJECT. 2017. Recommendations: Building a creative museum. [online]. 2017. [cit. 2018-09-10]. Dostupné na internete: $<\mathrm{http}: / /$ creative-museum.net/c/be-a-creative-museum/>

DCMS. 1998. Creative Industries Mapping Documents 1998. [online]. 1998. [cit. 2018-09-10] Dostupné na internete: <https:/www.gov.uk/government/ publications/creative-industries-mapping-documents-1998>

DCMS. 2005. Understanding the Future: Museums and 21st Century Life. [online]. London: DCMS, 2005. 26 p. [cit. 2018-09-10]. Dostupné na internete: $<$ http://webarchive.nationalarchives.gov.uk/+/http:/www.culture.gov. uk/images/publications/understanding_the_future_responses.pdf>

EURLEX. 2009. Decision No. 1350/2008/EC of the European Parliament and of the Council concerning the European Year of Creativity and Innovation (2009). [online]. 2008. [cit. 2018-09-10] Dostupné na internete: $<$ https://eurlex.europa.eu/eli/dec/2008/1350/oj>

FLORIDA, R. 2012. The Rise of the Creative Class. 2. vyd. New York: Basic Books, 2012. 483 p. ISBN 978-0-465-02993-8.

HOWKINS, J. The Creative Economy: How People Make Money from Ideas. London: Penguin Books Ltd., 2013. 304 p. ISBN 978-0-14197-703. 
JURČOVÁ, M. 2003. Tvorivost' - jej koncepčný rámec a výskumný potenciál v CEVIT. In Človek a spoločnost’. ISSN 1335-3608, 2003, roč. 6, č. 3.

MIŠÚNOVÁ, E. 2013. Vplyv kreativity na zatraktívnenie muzeálnych zariadení. In 4. Mezinárodní kolokvium o cestovním ruchu [online]. Brno: Masarykova univerzita, 2013. [cit. 2018-10-10]. Dostupné na internete: <https://www.econ.muni.cz/do/econ/soubory/katedry/kres/3910085/10619195/ sbornik-kolokviumCR2013-final.pdf> ISBN 978-80-210-6644-1, s. 85-94.

OECD. 2014. Tourism and the Creative Economy. In OECD Studies on Tourism. [online]. [cit. 2017-11-10]. Dostupné na internete: <http://dx.doi.org/ 10.1787/9789264207875-en>

PLAČEK, M. - BÓNA, M. Encyklopédia slovenských hradov. Bratislava: Slovart, 2007, 391 s. ISBN 978-80-8085-287-0.

RICHARDS, G. - RAYMOND, C. Creative tourism. In ATLAS News [online]. 2000, no. 23, pp. 16-20. [cit. 2018-10-10]. Dostupné na internete: $<$ https://www.academia.edu>

RICHARDS, G. - WILSON, J. Tourism, Creativity and Development. Oxon: Routledge, 2007. 346 p. ISBN 978-0-415-42756-2.

SANO, H. 2016. Theoretical consideration on creative tourism. In Journal of Global Tourism Research. vol. 1, no. 2.

SNM. 2018. Aktuálne výstavy: Kelti z Bratislavy. [online]. 2018. [cit. 2018-09-10] Dostupné na internete: <http://www.snm.sk/?historicke-muzeum-aktualnevystavy\&clanok=kelti-z-bratislavy $>$

TAN, S. K. - LUH, D. B. - KUNG, S. F. 2014. A Taxonomy of Creative Tourists in Creative Tourism. In Tourism Management. vol. 42, pp. 248-259.

ULLRICH, W. 2016. Der kreative Mensch: Streit um eine Idee. Salzburg: Residenz Verlag, 2016. 120 p. ISBN 9783701733880.

UNWTO. 2018. Tourism and Culture Synergies. Madrid: UNWTO, 2018, 160 p. DOI: https://doi.org/10.18111/9789284418978

WALTL, CH. 2006. Museums for visitors: Audience development - A crucial role for successful museum management strategies. [online]. INTERCOM 2006 Conference Paper [cit. 2018-09-10]. Dostupné na internete: <http://intercom. museum/documents/1-4Waltl.pdf>

\section{BRATISLAVA CASTLE AND ITS POTENTIAL FOR THE DEVELOPMENT OF THE CREATIVE TOURISM OFFER}

\section{Summary}

Creativity is currently the driving force of development of modern society and an integral part of strategies to boost economic growth, support innovation and develop individual skills as well as creative places. Concept of creativity is closely linked with museums, which are part of creative industries in general. 
The paper analyses the Bratislava Castle as the dominant attraction of tourism from the visitors' point of view, their needs and expectations connected to visitation of castle and Historical Museum and their satisfaction with the creative offer of this cultural heritage site. Based on the results of the questionnaire survey we identified the reasons of insufficient interest of Bratislava Castle's visitors for the visitation of Historical Museum located in its interiors. The most significant gaps were identified: (1) the absence of the official museum webpage as the tool of online promotion, (2) the old-fashioned interpretation and (3) the lack of interactive programmes for visitors conducted in interiors as well as exteriors of the museum. The further growth of visitors to the castle and the museum depends on the activisation of creative potential of the museum and its staff in cooperation with local creative people and representatives of creative industries (art, ICT, DIY community, craftsmen etc.). It must to be supported by holistic strategy of audience development, created by the museum management in cooperation with all relevant stakeholders (including stakeholders from the tourim industry).

PhDr. Zuzana Palenčíková, PhD.

\section{Bc. Zina Machničová}

Katedra cestovného ruchu

Fakulta stredoeurópskych štúdií

Univerzita Konštantína Filozofa v Nitre

Dražovská 4, 94974 Nitra

E-mail: zpalencikova@ukf.sk, zmachnicova@centrum.sk 